\title{
Analysis of Capital Budgeting In Cloud Papers Private Limited
}

\author{
CS. Gowtham Chakravarthy, S. Praveen Kumar
}

\begin{abstract}
Capital planning is the procedure where a business decides and assesses potential costs or speculations that are huge in nature. These uses and speculations incorporate undertakings, for example, constructing another plant or surges are putting resources into a long haul adventure. Periodically, a planned undertaking's lifetime money inflows and evaluated so as to decide if the potential returns created meet an adequate objective benchmark, otherwise called "speculation examination." The investigation was decided to decide the Capital Budgeting strategies utilized in venture evaluation choices among Companies recorded at the Nairobi Stock Exchange, and to discover the connection between capital planning systems and the budgetary exhibition of 47 organizations recorded in the Nairobi Stock. The reason for this investigation is to survey the capital planning writing over the previous decade. In particular, throughout the years 2004-2013, we survey works showing up in the real scholarly diaries in bookkeeping, money, and the board. Further, we audit the specific scholarly diaries in the board bookkeeping. We look at the recurrence of articles by diary and year distributed, the sort of research strategy connected, and the subject zone considered. We at that point audit the exploration discoveries by theme region.
\end{abstract}

Keywords: Capital Budgeting; Cash Flow; Discounted Cash Flow (DCF); Internal Rate of Return (IRR); Manufacture; Net Present Value (NPV); Payback Period; Present Value (PV)

\section{INTRODUCTION}

The capital planning choices expect essential significance because of its incredible effect on corporate productivity. Indeed, even the most productive firms face issues to the degree of chapter 11 , in the event that they settle on couple of such wrong choices. This requires the requirement for astute, shrewd and right capital consumption choices. What have been the capital planning practices pursued by business firms in the corporate area of Indian establishes the topic of my undertaking[1],[3],[5].

This undertaking analyzes capital planning and bookkeeping decisions in organization. The point of the task is to add to a comprehension of capital planning and distinguish factors that may clarify and anticipate it. The motivation behind the acquaintance is with depict the capital planning techniques and bookkeeping benchmarks that administration (in principle) should utilize and receive, feature pertinent speculations that may help clarify and

\footnotetext{
Revised Manuscript Received on July 22, 2019.

Mr CS. Gowtham chakravarthy, Department of MBA, Bharath Institute of Higher Education and Research, Chennai, India. Email: chakravins@gmail.com

Dr. S. Praveen Kumar, Department of MBA, Bharath Institute of Higher Education and Research, Chennai, India. Email: praveenkumar.mba@bharathuniv.ac.in
}

comprehend the functional conduct among the recorded organizations and their chiefs, present and talk about past capital planning and bookkeeping decision thinks about and clarify why this training matters from both organization and societal points of view[2],[4],[6]. Also, I will call attention to how this venture adds to current learning inside this field. The last reason for existing is to depict what (nearby) explore regions that are not secured by this work.

In current occasions, the effective portion of capital assets is a most vital capacity offinancial the executives. This capacity includes association's choice to contribute its resourcesin long haul resources like land, building offices, gear, vehicles, and so forth. Every one of these benefits areextremely imperative to the firm in light of the fact that, by and large, all the hierarchical benefits are derivedfrom the utilization of its capital in interest in resources which speak to a huge commitmentof money related assets, and these assets more often than not remain contributed over a significant lot of time[7],[9],[11].

The future advancement of a firm is dependent upon the capital venture ventures, there position of existing capital resources, or potentially the choice to forsake recently acknowledged endeavors which ends up being less appealing to the association than was initially suspected, and stripping the assets to the consideration of new thoughts and arranging. In a perfect world, organizations should seek after all ventures and openings that improve investor esteem.

The capital planning question is likely the most significant issue in corporate fund.

How a firm funds its tasks (the capital structure question) and how a firm deals with its momentary working exercises (the working capital inquiry) are positively issues of concern, yet it is the fixed resources that characterize the matter of the firm. Any firm has a colossal number of potential speculations. Every conceivable speculation is a choice accessible to the firm. A few choices are significant and some are most certainly not[8],[10],[12]. The substance of fruitful budgetary administration, obviously, is figuring out how to recognize which will be which. Mainstream techniques for capital planning incorporate net present worth (NPV), inward pace of return (IRR), limited income (DCF) and recompense period.

Two ways to deal with settling on capital planning choices use Discounted Cash Flow (DCF).One is the net present worth strategy (NPV), and other is the inside pace of return method(also called the time balanced pace of return technique).

An effective distribution of capital is the most significant money work in current occasions. It includes choices to submit company's assets to long haul resources. Such choices are will in general decide the estimation of organization/firm by impacting its development,

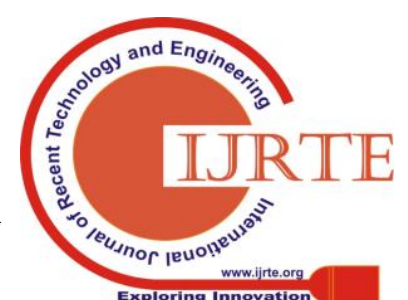




\section{Analysis of Capital Budgeting In Cloud Papers Private Limited}

productivity \&amp; chance[13], [15],[17].

Venture choices are commonly known as capital planning or capital consumption choices. It is smart choices to put current in long haul resources expecting long haul advantages company's venture choices would for the most part incorporate extension, procurement, modernization and substitution of long haul resources.

Such choices can be venture choices, financing choices or working choices. Venture choices manage speculation of association's assets in Long tern (fixed) Assets and/or Short term (Current) Assets. Choices relating to interest in Short term Assets fall under "Working Capital Management". Choices relating to interest in Long term Assets are delegated "Capital Budgeting" choices[14],[16], [18].

Capital planning choices are identified with assignment of investible assets to various long haul resources. They have long haul suggestions and influence the future development and productivity of the firm.In assessing such speculation recommendations, it is critical to deliberately consider the normal advantages of venture against the costs related with it.

Associations are much of the time looked with Capital Budgeting choices. Any choice that requires the utilization of assets is a capital planning choices. Capital planning is pretty much a nonstop procedure in any developing concern[19],[21],[23].

\section{A. Objectives}

The present research work was attempted with the general target to inspect in detail the capital planning examination. The particular targets of the investigation are:

- To study the Cloud Papers programming arrangements in regards to the capital planning systems or techniques utilized for assessing a speculation proposition.

- To study the criticality as far as level of trouble, significance and danger of various phases of capital planning process, and the elements influencing capital planning strategies which are being connected by the organizations.

- To examine the Cloud Papers programming arrangements concerning cost of capital and cost of value capital.

- To examine the various wellsprings of hazard, their alterations by organizations, and the corporate works on in regards to the capital planning procedures joining hazard.

\section{B. Need For the Study}

The venture study is attempted to investigate and comprehend the capital planning process in Cloud Papers programming arrangements, which gives mean introduction to viable ramifications of hypothesis information.
- To think about the organization's activity of utilizing different capital planning systems.

- To know how the organization gets assets from different assets.

\section{Limitations}

Lack of time is another constraining element, ie., the timetable time frame was not adequate to make the examination autonomously in regards to Capital Budgeting in Cloud Papers programming arrangements .

- The occupied timetable of the authorities in the Cloud Papers programming arrangements is another constraining component.

- Due to the bustling timetable authorities limited me to gather the total data about association.

- Non-accessibility of classified money related information.

- The study is directed in a brief period, which was not point by point in all viewpoints.

- All the systems of capital planning are not utilized in Cloud Papers programming arrangements .

- Therefore itwas conceivable to clarify just couple of techniques for capital planning.

\section{DATA COLLECTION}

Table - 1Discounted Cash Flow Methods Net Present Value

\begin{tabular}{|l|l|l|l|}
\hline YEAR & $\begin{array}{l}\text { DISCOUNTING } \\
\text { FACTOR } \\
@ 17 \%\end{array}$ & CASH INFLOWS & $\begin{array}{l}\text { PRESENT VALUE } \\
\text { OF r CASH } \\
\text { INFLOWS }\end{array}$ \\
\hline $\mathbf{2 0 1 2 - 1 3}$ & 0.855 & 4247.06 & 3631.24 \\
\hline $\mathbf{2 0 1 3 - 1 4}$ & 0.731 & 3448.82 & 2521.09 \\
\hline $\mathbf{2 0 1 4 - 1 5}$ & 0.625 & 2867.98 & 1792.49 \\
\hline $\mathbf{2 0 1 5 - 1 6}$ & 0.534 & 4538.89 & 2423.76 \\
\hline 2016-17 & 0.457 & 3796.20 & 1734.86 \\
\hline PRESENT VALUE & & 12103.44 \\
\hline Less Initial amount & & 5436.46 \\
\hline NET PRESENT VALUE & & \\
\hline
\end{tabular}

Internal rate of return method

FACTOR = Initial investment

Average cash inflow

Average cash inflow $=$

Total cash inflows

No of years

Published By: 
Average cash inflow $=$

$\underline{4247.06+3448.82+2867.98+4538.89+3796.20}$

Average cash inflow $=18898.95$

$$
5
$$

Average cash inflow $=3779.79$

FACTOR VALUE $=6666.98$

$$
\overline{3779.79}
$$

\section{FACTOR VALUE $=\mathbf{1 . 7 6}$}

\begin{tabular}{|c|c|c|c|c|c|}
\hline Year & $\begin{array}{l}\text { Cash } \\
\text { Inflows }\end{array}$ & $\begin{array}{l}\text { Discounting } \\
\text { factor@ } @ 40 \%\end{array}$ & $\begin{array}{l}P \text { V of CIF } \\
@ 40 \%\end{array}$ & $\begin{array}{l}\text { Discounting } \\
\text { factor@50\% }\end{array}$ & $\begin{array}{l}\text { P V of CIF } \\
@ 50 \%\end{array}$ \\
\hline 2012-13 & 4247.06 & 0.714 & 3032.40 & 0.667 & 2022.61 \\
\hline 2013-14 & 344.82 & 0.510 & 1758.90 & 0.444 & 1531.28 \\
\hline 2014-15 & 2864.98 & 0.364 & 1043.95 & 0.296 & 848.92 \\
\hline 2015-16 & 4538.89 & 0.260 & 1180.11 & 0.198 & 898.70 \\
\hline 2016-17 & 3796.20 & 0.186 & 699.40 & 0.132 & 501.10 \\
\hline & & & 7714.76 & & 5802.61 \\
\hline
\end{tabular}

Table - 4 Calculation Of Present Value Of Cash Inflow

$\mathrm{IRR}=\mathrm{A}+\mathrm{C}-\mathrm{O} \quad \mathrm{X}(\mathrm{B}-\mathrm{A})$

$$
\text { C - D }
$$

Where $\mathrm{A}=40$

$$
\begin{aligned}
& B=50 \\
& C=7714.76 \\
& D=5802.61 \\
& O=6666.98 .
\end{aligned}
$$

$$
7714.76-6666.98 \quad X(50-40)
$$

$\mathrm{IRR}=40+\overline{7714.76-5802}$

$\mathrm{IRR}=40+1047.78 \times 10$

1912.15

$\mathrm{IRR}=40+5.48 \mathrm{IRR}=\mathbf{4 5 . 4 8}$

\section{PROFITABILITY INDEX METHOD}

The profitability index is an index that attempts to identify the relationship between the costs and benefits of a proposed project.

\begin{tabular}{|l|l|l|l|}
\hline YEAR & $\begin{array}{l}\text { DISCOUNTING } \\
\text { FACTORS@ 17\% }\end{array}$ & CASH INFLOWS & $\begin{array}{l}\text { P V OF CASH } \\
\text { INFLOWS }\end{array}$ \\
\hline $2012-2013$ & 0.855 & 4247.06 & 3631.24 \\
\hline $2013-2014$ & 0.731 & 3448.82 & 2521.09 \\
\hline $2014-2015$ & 0.625 & 2867.98 & 1792.49 \\
\hline $2015-2016$ & 0.534 & 4538.89 & 2423.76 \\
\hline $2016-2017$ & 0.457 & 3796.20 & 1734.86 \\
\hline TOTAL P V of CIF & & 12103.44 \\
\hline
\end{tabular}

\section{Formula}

PROFITABILITY INDEX $=$ Present value of CIF

\section{Initial investment}

PROFITABILITY INDEX $=\frac{12103.44}{6666.98}$

PROFITABILITY INDEX $=1.15$

\section{RESULTS}

- Since the capital put resources into resources are recuperated inside a brief time of 1.60 year. The proposition is reasonable to theCloud Papers programming arrangements organization.

- Account pace of return works out to be $56.94 \%$.

- $\quad$ Net Present Value is Very high that is 5436.46 lakhs.

- Profitability record or cost - advantage proportion is 1.15. So the undertaking is reasonable[20],[22],[24].

- The Internal pace of return exercise to be 45.48 .

\section{DISCUSSIONS}

There must to be fitting spending control

- Orders persuaded should be fitting control

- There should be proficient way masterminding

- Have a game plan set up and consolidate your spending limit to it. Planning to your course of action "necessitates that spending decisions be made in perspective on veritable salary, rather than on conditions that such spending may (or may not) immediate."

- Team effort with the objective that divisions and units have a more clear cognizance of their needs. What's more, also the all inclusive community in your back division, having people with their pulse on the various workplaces can give you the data you need to make careful desires and set reasonable spending plans[25],[27],[29].

- Though the conditions in India have improved fundamentally after financial changes,

- There is a need to think about the effect of tax collection and 


\section{Analysis of Capital Budgeting In Cloud Papers Private Limited}

government strategies on capital planning choices of firms in India.

- As these choices influence the long haul future survival and development of the association, it would likewise be fascinating to ponder whether the capital planning leaders ar getting any extraordinary motivating forces or generally for taking such choice which produce wanted outcomes.

\section{CONCLUSION}

Capital planning choice is a complete and tedious assignment. It is a patterned procedure, which begins with age of proposition and winds up with checking and proceeded with revaluation of the recommendations. The investigation has uncovered that there are sure deficiencies and entanglements at various phases of capital planning choice. The starts of the capital venture thought and undertaking definition are brought together[26],[28],[30]. Staff working in the plants are not completely associated with the procedure. The subject of screening the proposition figured does not rise, as there were predetermined number of recommendations. For evaluating the screened recommendations, pay back strategy is utilized. DCF methods were not considered however there was degree for utilizing such procedures. The plants had a clear strategy for actualizing the recommendations. In any case, the administration did not pursue the time period, which at last brought about time and cost invade. The examination of fluctuation among 'gauge' and 'genuine' with reference to chosen markers has shown that appraisals have never been sensible as the suppositions in regards to evaluations were not logically made[31],[33]. Every factor considered showed a wide difference between the genuine and anticipated nearly in every one of the years under survey. The real was significantly less than the anticipated one demonstrating the need to attempt a lot of remedial measures in the readiness of capital use proposition.

\section{REFERENCES}

1) BharthVajan R., Ramachandran S.,Psychographic dimensions of training,2016,International Journal of Pharmacy and Technology,V-8,I-4,P-23727-23729

2) Balakrishnan P., Bharthvajan R.,A study on human resource planning in hospitals in Chennai City,2014,International Journal of Applied Engineering Research,V-9,I-22,P-7503-7507

3) Priyadarsini P., Bharthvajan R.,Role of emotional intelligence training programme in reducing the stress of the nurses,2014,International Journal of Applied Engineering Research,V-9,I-22,P-7411-7421

4) Kerinab Beenu G., Bharthvajan R.,Empirical analysis on the cosmetic buying behavior of young women in South India,2014,International Journal of Applied Engineering Research,V-9,I-22,P-7361-7366

5) Balakrishnan P., Bharthvajan R.,Whistling in the wind,2014,International Journal of Applied Engineering Research,V-9,I-22,P-7586-7593

6) Krishnan B., Peter M.,Health hazards of Indian Bpo employee-an alarming issue,2014,International Journal of Applied Engineering Research,V-9,I-22,P-7336-7341

7) Kerinab Beenu G.H., Peter M.,Role of insurance in economic development,2014,International Journal of Applied Engineering Research,V-9,I-22,P-7532-7539

8) Balakrishnan P., Peter M., Priyadarsini P.,Efficiency of safety measures for wellbeing of employees in manufacturing industry,2014,International Journal of Applied Engineering Research,V-9,I-22,P-7376-7382

9) Anbarasi M., Praveen Kumar S.,Online sales promotions of herbal products and its effectiveness towards tanisha.com,2019,Indian Journal of Public Health Research and Development,V-10,I-1,P-195-200

10) Anbarasi M., Praveen Kumar S.,Various online marketing and promotions strategies to improve the validation towards the organic products in the pharmaceutical sectors,2019,Indian Journal of Public Health Research and Development,V-10,I-1,P-263-269

11) Loganathan R., Praveen Kumar S.,Grievance handling a key factor for solving issues of employees in an organization,2014,International Journal of Applied Engineering Research,V-9,I-22,P-7483-7491

12) Loganathan R., Praveen Kumar S.,Study on preference of private label brands in super and Hypermarkets,2014,International Journal of Applied Engineering Research,V-9,I-22,P-7327-7335

13) Smitha M., Praveen Kumar S.,Understanding stress and its managementamong the nurses in Chennai city,2014,International Journal of Applied Engineering Research,V-9,I-22,P-7560-7565

14) Kerinab Beenu G.H., Praveen Kumar S.,A study on the investment behavior of Chennai investors in mutual fund schemes,2014,International Journal of Applied Engineering Research,V-9,I-22,P-7520-7525

15) Loganathan R., Praveen Kumar S.,Retention strategies key for organizational productivity,2014,International Journal of Applied Engineering Research,V-9,I-22,P-7443-7447

16) Pavithra J., Ganesan M., Brindha G.,State wise analysis of microfinance sector in India,2016,International Journal of Pharmacy and Technology,V-8,I-4,P-23417-23432

17) Pavithra J., Ganesan M.,A comparative study on microfinance in India and abroad,2016,International Journal of Applied Business and Economic Research,V-14,I-8,P-5471-5476

18) Pavithra J., Ganesan M.,A study on awareness and impact of micro-financial schemes,2016,International Journal of Applied Business and Economic Research,V-14,I-8,P-5449-5460

19) Senthilmurugan P., Pavithra J.,Consumer preference towards organised retailing with reference to Big Bazaar,2014,International Journal of Applied Engineering Research,V-9,I-22,P-7469-7475

20) Senthilmurugan P., Pavithra J.,Implication of social media marketing in growing healthcare industry,2014,International Journal of Applied Engineering Research,V-9,I-22,P-7448-7456

21) Loganathan R., Pavithra J.,Consumer perception towards private label brand over other brands in super markets and hypermarkets,2014,International Journal of Applied Engineering Research,V-9,I-22,P-7355-7360

22) Kerinab Beenu G., Pavithra J.,Tradeâ€"off between liquidity and profitability in logistics industry,2014,International Journal of Applied Engineering Research,V-9,I-22,P-7398-7401

23) Kerinab Beenu G., Pavithra J.,A study on the prospective consumerâ€TM perception towards utility cars in Chennai city,2014,International Journal of Applied Engineering Research,V-9,I-22,P-7526-7531

24) Pavithra J., Dilli Babu P., Ambuli T.V.,A study on budgetary control at Maruti Service Masters, Chennai,2014,International Journal of Applied Business and Economic Research,V-12,I-2,P-151-161

25) Pavithra J., Dilli Babu P., Ambuli T.V.,A study on customer satisfaction of retro Garments Pvt Ltd, Chennai,2014,International Journal of Applied Business and Economic Research,V-12,I-2,P-381-391

26) Kerinab Beenu G.H., Pavithra J., Senthilmurugan P.,A study on the influence of promotional activities for TATA ARIA among consumers in Chennai,2014,International Journal of Applied Engineering Research,V-9,I-22,P-7572-7578

27) Vijayaragavan S.P.,An investigative expert that's general FBG sensors,International Journal of Mechanical Engineering and Technology,V-8,I-8,PP-1500-1505,Y-2017

28) Vijayaragavan S.P.,Equalization routing protocol for Wi-Fi sensor strategy,International Journal of Mechanical Engineering and Technology,V-8,I-8,PP-1662-1666,Y-2017

29) Karthik B., Kiran Kumar T.V.U., Vijayaragavan P., Bharath Kumaran E.,Design of a digital PLL using 0.35 $\hat{\mathrm{I}}^{1} / 4 \mathrm{~m}$ CMOS technology,Middle East Journal of Scientific Research,V-18,I-12,PP-1803-1806,Y-2013

30) Kanniga E., Selvaramarathnam K., Sundararajan M.,Kandigital bike operating system,Middle - East Journal of Scientific Research, V

31) Jasmin M., Vigneshwaran T., Beulah Hemalatha S.,Design of power aware on chip embedded memory based FSM encoding in FPGA,International Journal of Applied Engineering Research,V-10,I-2,PP-4487-4496,Y-2015

32) Jasmin M.,Optimization techniques for low power VLSI circuits,Middle East Journal of Scientific Research,V-20,I-9,PP-1082-1087,Y-2014

33) Jasmin M., Vigneswaran T.,Fuzzy controller for error control of on - Chip communication,2017 International Conference on Algorithms, Methodology, Models and Applications in Emerging Technologies, ICAMMAET 2017,V-2017-January,I-,PP-1-5,Y-2017 


\section{AUTHORS PROFILE}

Mr CS. Gowtham chakravarthy Assistant Professor, Department of MBA, Bharath Institute of Higher Education and Research, Chennai, India.

Dr. S. Praveen Kumar Professor, Department of MBA, Bharath Institute of Higher Education and Research, Chennai, India. 